\title{
Secukinumab for ankylosing spondylitis and psoriatic arthritis
}

\author{
This article was published in the following Dove Press journal: \\ Therapeutics and Clinical Risk Management \\ 21 October 2016 \\ Number of times this article has been viewed
}

\author{
Ennio Lubrano \\ Fabio Massimo Perrotta \\ Dipartimento di Medicina e Scienze \\ della Salute "Vincenzo Tiberio", \\ Università degli Studi del Molise, \\ Campobasso, Italy
}

\begin{abstract}
The treatment of ankylosing spondylitis (AS) and psoriatic arthritis (PsA) positively changed since the introduction of anti-TNF $\alpha$ drugs. These treatments were shown to reduce the symptoms and signs of the diseases and improve the quality of life. However, a variable percentage of patients do not respond to anti-TNF $\alpha$ or can exhibit a loss of response and, furthermore, despite anti-TNF $\alpha$ drugs' proven efficacy in reducing peripheral radiographic progression in PsA, the impact in reducing radiographic damage in AS is still debated. Recently, the discovery of new pathogenic mechanisms paved the way to the development of new drugs that target other pro-inflammatory cytokines. In particular, the inhibition of interleukin (IL)-17, which is the principal cytokine produced by Th17 lymphocytes, a pro-inflammatory subset involved in both inflammation and new bone formation in AS and PsA, demonstrated promising results. The new molecule secukinumab, an IL-17A inhibitor, showed its efficacy and safety in phase III randomized clinical trials in AS and PsA and is the first non-anti-TNF $\alpha$ biologic approved for the treatment of AS, providing a useful alternative treatment strategy in both diseases. The aim of this article was to review the pathophysiological basis, the efficacy and the safety of secukinumab treatment in AS and PsA patients.
\end{abstract}

Keywords: anti IL-17, ankylosing spondylitis, psoriatic arthritis, secukinumab, treatment

\section{Introduction}

Ankylosing spondylitis (AS) is a chronic systemic inflammatory disease that predominantly affects the axial skeleton, with a possible peripheral and extra-articular involvement. The global prevalence is between $0.1 \%$ and $1.4 \%$ and patients with this disease may present diminished physical function and quality of life due mainly to the loss of spinal mobility. ${ }^{1,2}$

Psoriatic arthritis (PsA) is a chronic inflammatory disease characterized by the association of arthritis and psoriasis and by variable clinical manifestations and course, that potentially could lead to functional disability and poor quality of life. ${ }^{3}$ Both diseases belong to the group of spondyloarthritis ( $\mathrm{SpA}$ ) and share some clinical, radiological, genetic, immune, and pathogenic factors, such as the presence of peripheral arthritis, enthesitis, dactylitis, psoriasis, axial involvement, extra-articular manifestations, and common cytokine network alterations. ${ }^{4,5}$ The introduction of TNF $\alpha$ inhibitors positively changed the outcome of AS and PsA patients. Data from over 15 years of interventional trial and clinical practice experiences with anti-TNF $\alpha$ demonstrated its efficacy in all PsA domains (peripheral arthritis, axial involvement, enthesitis, dactylitis and extra-articular manifestations). These drugs also show effectiveness in the improvement of function, disease activity, pain, and quality of life in AS patients. ${ }^{6-12}$ In recent years, however, a more in-depth understanding of
Correspondence: Ennio Lubrano Dipartimento di Medicina e Scienze della Salute "Vincenzo Tiberio", Università degli Studi del Molise, Via Giovanni Paolo II, C/da Tappino, 86100 Campobasso, Italy Tel +390874 404745 Fax +390874 404745

Email enniolubrano@hotmail.com cc) and incorporate the Creative Commons Attribution - Non Commercial (unported, v3.0) License (http///creativecommons.org/licenses/by-nd/3.0/). By accessing the work you hereby accept the Terms. Non-commercial uses of the work are permitted without any further permission from Dove Medical Press Limited, provided the work is properly attributed. For permission for commercial use of this work, please see paragraphs 4.2 and 5 of our Terms (https://www.dovepress.com/terms.php). 
pathophysiology of SpAs led to the discovery of several cell pathways and cytokines involved in the pathological process of synovitis and enthesitis and in the other clinical domains of the diseases. Th cells producing interleukin (IL)-17 (Th17 cells, which also produce TNF $\alpha$, IL-21, and IL-22) play a substantial role in chronic inflammatory conditions and seem to drive both erosions and new bone formation in the joints of PsA and AS patients. ${ }^{13-15}$ With this background, the aim of this article is to review the current role of anti-IL-17A secukinumab in the treatment of AS and PsA.

\section{IL-I 7A blockade: a new treatment pathway}

In chronic inflammatory diseases, interleukin's production is mandatory for the development of clinical manifestations, and several evidences showed that IL-12 and IL-23 play an important role in the development of SpA. Some studies reported that mutations in IL-23 receptor gene and IL-12 gene were associated with the susceptibility to psoriasis, inflammatory bowel diseases and SpA, ${ }^{16-18}$ and, furthermore, IL-12 and IL-23 are involved in the Th1/Th17 immune responses, that are the two major phenotypes present in SpA. Moreover, Th17 cells are increased in AS patients and increase from baseline in patients who do not respond to anti-TNF treatment, suggesting their role in the pathogenesis of the disease. IL23/IL-17 axis is also strongly linked to SpA pathogenesis: studies in humans show that production of and sensitivity to IL-23 is increased and IL-23-responsive cells are expanded in many forms of SpA. IL-23 is essential for the proliferation and terminal differentiation of $\mathrm{CD}^{+}{ }^{+} \mathrm{Th} 17 \mathrm{~T}$ cells, maintaining IL-17 production, and ultimately driving the pathogenicity of the cells. ${ }^{19-25}$ In support of these findings, Sherlock et al demonstrated that overexpression of IL-23 by hepatic injection of IL-23 minicircle drives enthesitis and aortitis in mice, in a process involving IL-22 and IL-17. The same authors found resident entheseal $\mathrm{CD}^{+}{ }^{+} \mathrm{CD} 4^{-} \mathrm{CD} 8^{-} \mathrm{T}$ cells sensitive to IL-23 and producing IL-17 and IL-22 in mouse models of SpA. ${ }^{26}$ IL-17 family includes six members (IL-17A-F). Several studies demonstrated the relevant role of IL-17A in the pathogenesis of SpA: data from mouse models showed the role of IL-17A in the synovial inflammation and joint destruction during collagen-induced arthritis. ${ }^{25}$ In humans, polymorphisms associated with susceptibility to $\mathrm{SpA}$ are present in genetic loci involved in IL-17 signaling. IL-17 receptor A and T cells actively producing Il-17 are elevated in synovial fluid and in psoriatic plaques of PsA patients, and levels of circulating Th17 cells were also higher in patients with both AS and PsA in comparison with patients with rheumatoid arthritis. ${ }^{27}$ Furthermore, $\mathrm{CD} 4^{-} / \mathrm{CD}^{+} \mathrm{IL}-17^{+}$ cells were detected in PsA patients' synovial fluid. ${ }^{28}$ IL-17 is also crucial in the development of inflammation and bone resorption/proliferation in SpA: IL-17 stimulated bone resorption in combination with $\mathrm{TNF} \alpha$ in fetal mouse long bones and induced the expression of the receptor activator of NF $\kappa B$ ligand (RANKL - the osteoclast differentiation factor) in osteoclast-supporting cells. ${ }^{29}$ Furthermore, Th17 cells seems to drive bone formation through the action of IL-22 on osteoblasts. ${ }^{24}$ On this basis, the efficacy and effectiveness of the inhibition of IL-12/23 - IL-17 axis were tested in several auto-immune diseases, such as multiple sclerosis, rheumatoid arthritis, psoriasis, and SpA, both on the inflammatory and bone damage aspects.

\section{Secukinumab for AS}

Different anti-IL-17 agents were developed and are currently in phase II and III trials for the treatment of rheumatic and inflammatory diseases. ${ }^{8}$ Secukinumab (Cosentyx ${ }^{\circledR}$; Novartis International AG, Basel, Switzerland) was one of the first molecules that targeted free Il-17A. Anti-IL-17A secukinumab was evaluated in phase II and III trials on patients with AS. The first study that provided clinical evidences of efficacy of secukinumab in AS was a 28-week multicenter, randomized, double-blind clinical trial published by Baeten et al..$^{30}$ In this study, 30 patients, $18-65$ years of age, with active AS defined by the modified New York criteria were enrolled. Of these, 24 patients received two infusions of secukinumab $10 \mathrm{mg} / \mathrm{kg}$ given intravenously 3 weeks apart and 6 patients received placebo. The primary endpoint (Assessment of Spondycoarthritis International Society [ASAS] 20 at week 6) was achieved by $59 \%$ of patients on secukinumab vs $24 \%$ on placebo with a $99.8 \%$ probability that secukinumab is superior to placebo. Patients in the secukinumab arm also achieved an ASAS 40 response, reduction of CRP levels and improvement in quality of life. One serious adverse event (subcutaneous abscess caused by Staphylococcus aureus) occurred in the secukinumab-treated group. ${ }^{30}$ The study was followed by three phase III randomized controlled trials (MEASURE 1-2-3). In MEASURE 1, a total of 371 AS patients received intravenous secukinumab (10 $\mathrm{mg} / \mathrm{kg}$ of body weight) or matched placebo at weeks 0,2 , and 4, followed by subcutaneous secukinumab (150 mg or $75 \mathrm{mg}$ ) or matched placebo every 4 weeks starting at week 8 while in the MEASURE 2 study 219 patients with AS received subcutaneous secukinumab (150 mg or $75 \mathrm{mg}$ ) or matched placebo at baseline at weeks 1, 2, and 3; and every 4 weeks starting at week 4 . After 16 weeks of treatment, patients in the placebo group were randomly reassigned to 
subcutaneous secukinumab at a dose of $150 \mathrm{mg}$ or $75 \mathrm{mg} .{ }^{31}$ In both studies disease-modifying antirheumatic drug therapy and previous anti-TNF therapy were allowed, however, about $70 \%$ of patients in the two studies were anti-TNF naïve. Secukinumab treatment showed efficacy in reducing the symptoms and signs of the disease: in the MEASURE 1 study, ASAS 20 response rate at 16 weeks was $61 \%, 60 \%$, and $29 \%$ for subcutaneous secukinumab at doses of $150 \mathrm{mg}$, $75 \mathrm{mg}$, and for placebo, respectively $(P<0.001$ for both comparisons with placebo). In the MEASURE 2 study ASAS 20 response was achieved by a rate of $61 \%, 41 \%$, and $28 \%$ for subcutaneous secukinumab at doses of $150 \mathrm{mg}, 75 \mathrm{mg}$, and for placebo, respectively $(P<0.001$ for the $150 \mathrm{mg}$ dose and $P=0.10$ for the $75 \mathrm{mg}$ dose).${ }^{31}$ In MEASURE 2, all secondary endpoints except ASAS partial remission were met with subcutaneous secukinumab treatment at a dose of $150 \mathrm{mg}$. Despite the higher exposure with the intravenous regime loading, no incremental benefits were observed in efficacy with the intravenous in comparison to subcutaneous administration. The rate of adverse events was similar in both studies, however, authors reported that rates of grade 3 or 4 neutropenia, candida infections, and Crohn's disease were 0.7, 0.9, and 0.7 cases per 100 patient-years, respectively, in the arm of secukinumab-treated patients. ${ }^{31}$ The MEASURE 3 study is still ongoing with the estimated study completion date of November 2017 (www.ClinicalTrials.gov/ct2/show/ NCT02008916). On the basis of these two randomized trials, secukinumab was approved for the treatment of active AS. To demonstrate the clinical efficacy, safety and tolerability of secukinumab compared to placebo in patients with nonradiographic axial $\mathrm{SpA}$, a phase III randomized controlled trial is still ongoing (www.ClinicalTrials.gov/ct2/show/ NCT02696031).

Data from a pilot study by Baraliakos et al showed the efficacy of secukinumab in reducing MRI bone marrow edema in AS patients: in 10 patients with AS treated with secukinumab, $87 \%$ of inflammatory lesions present at vertebral edges, at baseline, resolved after 94 weeks of treatment. ${ }^{32}$ The reduction of MRI inflammation is of crucial importance in order to stop radiographic progression of the disease. In a recent report, Baraliakos et al analyzed the data from the MEASURE 1 study and demonstrated that approximately $80 \%$ of patients randomized to secukinumab showed no radiographic progression (modified Stoke Ankylosing Spondylitis Spinal Score - mSASSS change $\leq 0$ ) from baseline to week 104 and, furthermore, new syndesmophytes were found in only $5 \%$ of patients who were without syndesmophytes after 104 weeks of treatment. ${ }^{33}$ The study confirmed that male sex (mean mSASSS change $0.38 \pm 2.79$ vs $0.08 \pm 1.58$ in females), elevated CRP levels (0.47 \pm 2.66 vs $0.02 \pm 2.27$ in patients with normal CRP) and presence of syndesmophytes $(0.47 \pm 3.20$ vs $0.02 \pm 0.26$ in patients with no syndesmophytes) were risk factors for radiographic spinal damage progression. ${ }^{33}$

\section{Secukinumab for PsA}

Recent evidence showed the role of Th17 cells, and other immune cells, as regulators of psoriatic skin inflammation. As discussed above, IL-17A is the principal cytokine produced by Th17. It stimulates keratinocytes to produce chemokines, cytokines, and other pro-inflammatory mediators, thereby enabling IL-17A to bridge the innate and adaptive immune systems to sustain chronic inflammation. In the same way, IL-17A is essential to maintain entheseal and joint inflammation in patients with PsA..$^{8,14,26,34}$ For these reasons anti-IL-17A secukinumab was tested in psoriasis patients in two phase III, double-blind, randomized trials, ERASURE and FIXTURE, and showed a higher efficacy in Psoriasis Severity Index [PASI] 75 response compared to placebo and etanercept with a similar rate of infections compared to etanercept. ${ }^{35}$ In another trial on plaque psoriasis, secukinumab was found to be superior to ustekinumab with respect to PASI 90 response at week $16 .{ }^{36}$ Anti-IL-17 drug secukinumab was also tested in PsA in two phase III, doubleblind, placebo-controlled studies. In the FUTURE 2 study adults with active PsA were randomly assigned to receive subcutaneous placebo or secukinumab $300 \mathrm{mg}, 150 \mathrm{mg}$, or $75 \mathrm{mg}$ once a week from baseline and then every 4 weeks from week 4. A significantly higher proportion of patients achieved an American College of Rheumatology (ACR) 20 at week 24 with secukinumab $300 \mathrm{mg}$ (54\%), $150 \mathrm{mg}$ (51\%), and $75 \mathrm{mg}$ (29\%) patients vs placebo (15\%) patients. ${ }^{37}$

In this study secukinumab demonstrated its efficacy in both anti-TNF naïve and anti-TNF exposed patients; however anti-TNF naïve PsA patients seemed to have a better response. ${ }^{38}$

Up to week 16, the most common adverse events were upper respiratory tract infections in particular, nasopharyngitis. Serious adverse events were reported by five ( $5 \%)$, one $(1 \%)$, and four (4\%) patients in the secukinumab $300 \mathrm{mg}$, $150 \mathrm{mg}$, and $75 \mathrm{mg}$ groups, respectively, compared with two $(2 \%)$ in the placebo group. No deaths were reported. ${ }^{38}$ In a recent study, efficacy of secukinumab was shown regarding its inhibition of radiographic progression in patients with active PsA through 52 weeks of therapy. ${ }^{39}$

In the FUTURE 1 study, PsA patients were randomized $1: 1: 1$ to receive intravenous secukinumab $10 \mathrm{mg} / \mathrm{kg}$ at weeks 0,2 , and 4 followed by subcutaneous secukinumab 
Table I Published and still ongoing randomized controlled trials of secukinumab treatment in AS and PsA

\begin{tabular}{|c|c|c|c|c|}
\hline Disease & Reference & Type of study & Name & Description \\
\hline \multirow[t]{6}{*}{ AS } & Baeten et al, ${ }^{30} 2013$ & Phase II & & $\begin{array}{l}\text { Anti-interleukin- I7A monoclonal antibody secukinumab in treatment of } \\
\text { ankylosing spondylitis: a randomized, double-blind, placebo-controlled trial }\end{array}$ \\
\hline & Baeten et $\mathrm{al},{ }^{31} 2015$ & Phase III & MEASURE I & Secukinumab, an interleukin-I7A Inhibitor, in ankylosing spondylitis \\
\hline & Baeten et al, ${ }^{31} 2015$ & Phase III & MEASURE 2 & Secukinumab, an Interleukin- I7A Inhibitor, in ankylosing spondylitis \\
\hline & $\begin{array}{l}\text { ClinicalTrial.gov } \\
\text { Ongoing study }\end{array}$ & Phase III & & $\begin{array}{l}\text { A randomized, double-blind, placebo-controlled multicenter study of } \\
\text { secukinumab to evaluate the safety, tolerability and efficacy up to } 2 \text { years } \\
\text { in patients with active non-radiographic axial spondyloarthritis }\end{array}$ \\
\hline & $\begin{array}{l}\text { ClinicalTrial.gov } \\
\text { Ongoing study }\end{array}$ & Phase III & MEASURE 3 & $\begin{array}{l}\text { A randomized, double-blind, placebo-controlled phase III study of } \\
\text { secukinumab to demonstrate the efficacy at I } 6 \text { weeks and to assess } \\
\text { the long-term safety, tolerability and efficacy up to } 3 \text { years in subjects } \\
\text { with active ankylosing spondylitis }\end{array}$ \\
\hline & & Phase III & ASTRUM & $\begin{array}{l}\text { A randomized, double-blind, placebo-controlled multicenter study of } \\
\text { secukinumab (AIN457) to examine the clinical efficacy and the nonsteroidal } \\
\text { anti-inflammatory drug (NSAID)-sparing effect of secukinumab over } \\
16 \text { weeks in patients with ankylosing spondylitis }\end{array}$ \\
\hline \multirow[t]{4}{*}{ PsA } & Mease et $\mathrm{al}^{40} 2015$ & Phase III & FUTURE I & Secukinumab inhibition of interleukin- I7A in patients with psoriatic arthritis \\
\hline & Mclnnes et al, ${ }^{37} 2015$ & Phase III & FUTURE 2 & $\begin{array}{l}\text { Secukinumab, a human anti-interleukin-I7A monoclonal antibody, in patients } \\
\text { with psoriatic arthritis (FUTURE 2): a randomized, double-blind, placebo- } \\
\text { controlled, phase } 3 \text { trial }\end{array}$ \\
\hline & $\begin{array}{l}\text { ClinicalTrial.gov } \\
\text { Ongoing study }\end{array}$ & Phase III & FUTURE 4 & $\begin{array}{l}\text { A phase III, randomized, double-blind, placebo-controlled multicenter } \\
\text { study of subcutaneous secukinumab ( } 150 \mathrm{mg} \text { ) in pre-filled syringe, with } \\
\text { or without loading regimen, to demonstrate efficacy, safety and tolerability } \\
\text { up to } 2 \text { years in patients with active psoriatic arthritis }\end{array}$ \\
\hline & $\begin{array}{l}\text { ClinicalTrial.gov } \\
\text { Ongoing study }\end{array}$ & Phase III & FUTURE 5 & $\begin{array}{l}\text { Phase III, randomized, double-blind, placebo controlled multi-center study of } \\
\text { subcutaneous secukinumab ( } 150 \mathrm{mg} \text { and } 300 \mathrm{mg} \text { ) in prefilled syringe } \\
\text { to demonstrate efficacy (including inhibition of structural damage), safety, } \\
\text { and tolerability up to } 2 \text { years in subjects with active psoriatic arthritis }\end{array}$ \\
\hline
\end{tabular}

Abbreviations: AS, ankylosing spondylitis; PsA, psoriatic arthritis.

150 or $75 \mathrm{mg}$ every 4 weeks or matching placebo until week 24. In this study secukinumab treatment showed its efficacy in the resolution of enthesitis and dactylitis: $73.1 \%$ of patients treated with secukinumab $10 \mathrm{mg} / \mathrm{kg}$ intravenously and then $75 \mathrm{mg}$ subcutaneously had a resolution of dactylitis while $58.9 \%$ of patients treated with the same regime had resolution of enthesitis after 52 weeks of treatment. ${ }^{40}$ In a subanalysis of FUTURE 1, secukinumab treatment improved patient-reported outcomes in subjects with active PsA: secukinumab-treated patients reported greater least squares mean changes from baseline than those receiving placebo in patient global assessment of disease activity (-20.6 and $-20.0 \mathrm{vs}-7.4$, respectively), patient assessment of pain $(-20.8$ and -20.4 vs -6.7$)$, PsA quality of life $(-3.5$ and -3.2 vs -0.4$)$, Dermatology Life Quality Index ( -8.8 and -7.9 vs 0.7), and Functional Assessment of Chronic Illness TherapyFatigue (6.74 and 6.03 vs 4.00). ${ }^{41}$ This study demonstrated the efficacy of anti-IL-17 treatment in the improvement of the overall quality of life of patients, beyond the efficacy on inflammatory aspects of the disease.

Data from studies on patients withmoderate-to-severe plaque psoriasis seem to confirm a favorable safety and tolerability profile of secukinumab. A comprehensive analysis of pooled safety data from 10 phase II and III clinical studies in psoriasis with 3,430 subjects who received secukinumab or etanercept representing 2,725 subject-years of exposure, show comparable incidence rates of total serious and nonserious adverse events; serious and nonserious infections; malignant or unspecified tumors and adjudicated major adverse cardiovascular events over 52 weeks. ${ }^{42}$ Extension studies are ongoing to further confirm the longer-term safety experience with secukinumab in psoriasis. Table 1 shows the published and still ongoing randomized controlled trials of secukinumab treatment in AS and PsA patients.

\section{Conclusion}

The treatment of $\mathrm{SpA}$ still represents a challenge for rheumatologists, and improving standards of care in AS and PsA, for instance, is needed. ${ }^{43}$ Secukinumab has been approved for the treatment of AS and PsA by regulatory authorities and is playing an important role in the treatment of all SpA features, demonstrating promising results in the prevention of radiographic damage, regarding both the aspects of peripheral joint erosion in PsA and new bone 
formation in AS. Recently, secukinumab has been included in the recent EULAR update $2015^{44}$ and GRAPPA $2015^{45}$ recommendation for the treatment of PsA. Further studies, especially in a clinical practice setting, are necessary to better understand the efficacy and safety profile.

\section{Disclosure}

The authors declare that no funding was received to conduct the study described in the manuscript, or used to assist with the preparation of the manuscript. The authors declare no conflicts of interest in this work.

\section{References}

1. Braun J, Sieper J. Ankylosing spondylitis. Lancet. 2007;369(9570): 1379-1390.

2. Boonen A, van der Linden SM. The burden of ankylosing spondylitis. J Rheumatol Suppl. 2006;78:4-11.

3. Gladman DD, Antoni C, Mease P, Clegg DO, Nash P. Psoriatic arthritis: epidemiology, clinical features, course and outcome. Ann Rheum Dis. 2005;64 Suppl 2:ii14-ii17.

4. Garg N, van den Bosch F, Deodhar A. The concept of spondyloarthritis: where are we now? Best Pract Res Clin Rheumatol. 2014;28(5): 663-672.

5. Coates LC, Anderson RR, Fitzgerald O, et al. Clues to the pathogenesis of psoriasis and psoriatic arthritis from imaging: a literature review. J Rheumatol. 2008;35(7):1438-1442.

6. Spadaro A, Punzi L, Marchesoni A, et al. Switching from infliximab or etanercept to adalimumab in resistant or intolerant patients with spondyloarthritis: a 4-year study. Rheumatology (Oxford). 2010;49(6): $1107-1111$.

7. Fénix-Caballero S, Alegre-del Rey EJ, Castaño-Lara R, PuigventósLatorre F, Borrero-Rubio JM, López-Vallejo JF. Direct and indirect comparison of the efficacy and safety of adalimumab, etanercept, infliximab and golimumab in psoriatic arthritis. J Clin Pharm Ther. 2013; 38(4):286-293.

8. Lubrano E, Perrotta FM. Beyond TNF inhibitors: new pathways and emerging treatments for psoriatic arthritis. Drugs. 2016;76(6): 663-673.

9. Lubrano E, Parsons WJ, Perrotta FM. Assessment of response to treatment, remission, and minimal disease activity in axial psoriatic arthritis treated with tumor necrosis factor inhibitors. $J$ Rheumatol. 2016;43(5):918-923.

10. Perrotta FM, Marchesoni A, Lubrano E. Minimal disease activity and remission in psoriatic arthritis patients treated with anti-TNF- $\alpha$ drugs. J Rheumatol. 2016;43(2):350-355.

11. Spadaro A, Lubrano E, Marchesoni A, et al. Remission in ankylosing spondylitis treated with anti-TNF- $\alpha$ drugs: a national multicentre study. Rheumatology (Oxford). 2013;52(10):1914-1919.

12. Callhoff J, Sieper J, Weiß A, Zink A, Listing J. Efficacy of TNF $\alpha$ blockers in patients with ankylosing spondylitis and non-radiographic axial spondyloarthritis: a meta-analysis. Ann Rheum Dis. 2015;74(6):1241-1248.

13. Raychaudhuri SP, Raychaudhuri SK, Genovese MC. IL-17 receptor and its functional significance in psoriatic arthritis. Mol Cell Biochem. 2012;359(1-2):419-429.

14. Smith JA, Colbert RA. Review: The interleukin-23/interleukin-17 axis in spondyloarthritis pathogenesis: Th17 and beyond. Arthritis Rheumatol. 2014;66(2):231-241.

15. Spadaro A, Montepaone M, Lubrano E. A novel biological target for the treatment of psoriatic arthritis. Immunotherapy. 2014;6(5):515-518.

16. Cargill M, Schrodi SJ, Chang M, et al. A large-scale genetic association study confirms IL12B and leads to the identification of IL23R as psoriasis-risk genes. Am J Hum Genet. 2007;80(2):273-290.
17. Spadaro A, Lubrano E. Beyond anti-TNF $\alpha$ agents in psoriatic arthritis. Expert Rev Clin Immunol. 2013;9(6):507-509.

18. Duerr RH, Taylor KD, Brant SR, et al. A genome-wide association study identifies IL23R as an inflammatory bowel disease gene. Science. 2006;314(5804):1461-1463.

19. Xueyi L, Lina C, Zhenbiao W, Qing H, Qiang L, Zhu P. Levels of circulating Th17 cells and regulatory $\mathrm{T}$ cells in ankylosing spondylitis patients with an inadequate response to anti-TNF- $\alpha$ therapy. J Clin Immunol. 2013;33(1):151-161.

20. Shen H, Goodall JC, Hill Gaston JS. Frequency and phenotype of peripheral blood Th17 cells in ankylosing spondylitis and rheumatoid arthritis. Arthritis Rheum. 2009;60(6):1647-1656.

21. Wang X, Lin Z, Wei Q, Jiang Y, Gu J. Expression of IL-23 and IL-17 and effect of IL-23 on IL-17 production in ankylosing spondylitis. Rheumatol Int. 2009;29(11):1343-1347.

22. Wendling D. IL-23 and IL-17 in ankylosing spondylitis. Rheumatol Int. 2010;30(11):1547.

23. Prevosto C, Goodall JC, Hill Gaston JS. Cytokine secretion by pathogen recognition receptor-stimulated dendritic cells in rheumatoid arthritis and ankylosing spondylitis. J Rheumatol. 2012;39(10):1918-1928.

24. Kehl AS, Corr M, Weisman MH. Review: enthesitis: new insights into pathogenesis, diagnostic modalities, and treatment. Arthritis Rheumatol. 2016;68(2):312-322.

25. Lubberts E, Joosten LA, Oppers B, et al. IL-1-independent role of IL-17 in synovial inflammation and joint destruction during collagen-induced arthritis. J Immunol. 2001;167(2):1004-1013.

26. Sherlock JP, Joyce-Shaikh B, Turner SP, et al. IL-23 induces spondyloarthropathy by acting on ROR- $\gamma \mathrm{t}+\mathrm{CD} 3+\mathrm{CD} 4-\mathrm{CD} 8-$ entheseal resident T cells. Nat Med. 2012;18(7):1069-1076.

27. Jandus C, Bioley G, Rivals JP, Dudler J, Speiser D, Romero P. Increased numbers of circulating polyfunctional Th17 memory cells in patients with seronegative spondylarthritides. Arthritis Rheum. 2008; 58(8):2307-2317.

28. Menon B, Gullick NJ, Walter GJ, et al. Interleukin- $17+\mathrm{CD} 8+\mathrm{T}$ cells are enriched in the joints of patients with psoriatic arthritis and correlate with disease activity and joint damage progression. Arthritis Rheumatol. 2014;66(5):1272-1281.

29. Lee $Y$. The role of interleukin-17 in bone metabolism and inflammatory skeletal diseases. BMB Rep. 2013;46(10):479-483.

30. Baeten D, Baraliakos X, Braun J, et al. Anti-interleukin-17A monoclonal antibody secukinumab in treatment of ankylosing spondylitis: a randomised, double-blind, placebo-controlled trial. Lancet. 2013; 382(9906):1705-1713.

31. Baeten D, Sieper J, Braun J, et al. Secukinumab, an interleukin-17a inhibitor, in ankylosing spondylitis. N Engl J Med. 2015;373(26): 2534-2548.

32. Baraliakos X, Borah B, Braun J, et al. Long-term effects of secukinumab on MRI findings in relation to clinical efficacy in subjects with active ankylosing spondylitis: an observational study. Ann Rheum Dis. 2016;75(2): 408-412.

33. Baraliakos X, Deodhar A, Braun J, et al. Effect of interleukin-17A inhibition on spinal radiographic changes through 2 years in patients with active ankylosing spondylitis: results of a phase 3 study with secukinumab [abstract]. Arthritis Rheumatol. 2015;67 (suppl 10).

34. Lynde CW, Poulin Y, Vender R, Bourcier M, Khalil S. Interleukin 17A: toward a new understanding of psoriasis pathogenesis. $J$ Am Acad Dermatol. 2014;71(1):141-150.

35. LangleyRG,ElewskiBE,LebwohlM, etal. Secukinumabinplaquepsoriasisresults of two phase 3 trials. N Engl J Med. 2014;371(4):326-338.

36. Thaçi D, Blauvelt A, Reich $\mathrm{K}$, et al. Secukinumab is superior to ustekinumab in clearing skin of subjects with moderate to severe plaque psoriasis: CLEAR, a randomize controlled trial. J Am Acad Dermatol. 2015;73(3):400-409.

37. McInnes IB, Mease PJ, Kirkham B, et al. Secukinumab, a human antiinterleukin-17A monoclonal antibody, in patients with psoriatic arthritis (FUTURE 2): a randomised, double-blind, placebo-controlled, phase 3 trial. Lancet. 2015;386(9999):1137-4630. 
38. Kavanaugh A, McInnes IB, Mease PJ, et al. Efficacy of subcutaneous secukinumab in patients with active psoriatic arthritis stratified by prior tumor necrosis factor inhibitor use: results from the randomized placebo-controlled FUTURE 2 study. J Rheumatol. 2016;43(9): 1713-1717.

39. van der Heijde D, Landewé RB, Mease PJ, et al. Brief report: secukinumab provides significant and sustained inhibition of joint structural damage in a phase III study of active psoriatic arthritis. Arthritis Rheumatol. 2016;68(8):1914-1921.

40. Mease PJ, McInnes IB, Kirkham B, et al. Secukinumab inhibition of interleukin-17A in patients with psoriatic arthritis. N Engl J Med. 2015; 373(14):1329-1339.

41. Strand V, Mease P, Gossec L, et al. Secukinumab improves patientreported outcomes in subjects with active psoriatic arthritis: results from a randomised phase III trial (FUTURE 1). Ann Rheum Dis. Epub 2016 May 11.
42. van de Kerkhof PC, Griffiths CE, Reich K, et al. Secukinumab longterm safety experience: a pooled analysis of 10 phase II and III clinical studies in patients with moderate to severe plaque psoriasis. $\mathrm{J} \mathrm{Am} \mathrm{Acad}$ Dermatol. 2016;75(1):83-98.

43. Helliwell P, Coates L, Chandran V, et al. Qualifying unmet needs and improving standards of care in psoriatic arthritis. Arthritis Care Res (Hoboken). 2014;66(12):1759-1766.

44. Gossec L, Smolen JS, Ramiro S, et al. European League Against Rheumatism (EULAR) recommendations for the management of psoriatic arthritis with pharmacological therapies: 2015 update. Ann Rheum Dis. 2016;75(3):499-510.

45. Coates LC, Kavanaugh A, Mease PJ, et al. Group for research and assessment of psoriasis and psoriatic arthritis 2015 treatment recommendations for psoriatic arthritis. Arthritis Rheumatol. 2016; 68(5):1060-1071.
Therapeutics and Clinical Risk Management

\section{Publish your work in this journal}

Therapeutics and Clinical Risk Management is an international, peerreviewed journal of clinical therapeutics and risk management, focusing on concise rapid reporting of clinical studies in all therapeutic areas outcomes, safety, and programs for the effective, safe, and sustained use of medicines. This journal is indexed on PubMed Central, CAS,

\section{Dovepress}

EMBase, Scopus and the Elsevier Bibliographic databases. The manuscript management system is completely online and includes a very quick and fair peer-review system, which is all easy to use. Visit http://www.dovepress.com/testimonials.php to read real quotes from published authors. 